\title{
STUDI MUTU PRODUK IKAN JAPUH (Dussumieria acuta C.V.) ASAP KERING INDUSTRI RUMAH TANGGA DI DESA TUMPAAN BARU, KECAMATAN TUMPAAN
}

\author{
Gordianus P Lombongadil, Albert R Reo dan Hens Onibala
}

Fakultas Perikanan dan Ilmu Kelautan, Universitas Sam Ratulangi, Manado, Sulawesi Utara.

\begin{abstract}
ABSTRAK
Pengasapan merupakan salah satu cara pengolahan dan pengawetan ikan secara tradisional yang sudah dilakukan sejak dulu hingga kini, dengan tujuan untuk mengurangi kadar air dalam tubuh ikan serta membunuh atau menghambat pertumbuhan bakteri pembusuk. Ikan Japuh (Dussumieria acuta C.V) asap kering merupakan salah satu produk olahan Sulawesi Utara yang diproduksi dari industri rumah tangga yang berada di desa Tumpaan baru, Kecamatan Tumpaan, Kabupaten Minahasa Selatan. Saat ini ikan Japuh asap kering sudah dipasarkan sampai keluar daerah Sulawesi Utara.

Penelitian ini bertujuan untuk mengetahui mutu ikan Japuh asap kering yang diambil dari produksi rumah tangga di Desa Tumpaan Baru, Kecamatan Tumpaan. Metode yang digunakan dalam penelitian adalah metode eksploratif deskriptif, yaitu mengumpulkan data fakta yang telah tersedia di lapangan melalui pencatatan dan pengamatan secara terperinci dan sistematik. Secara garis besar tahaptahap pengolahan ikan Japuh asap kering meliputi persiapan bahan, pencucian ikan, pengaturan pada rak, Penirisan, pengasapan dan pengeringan. Sedangkan tahap-tahap penelitian yang dilakukan adalah sampel ikan Japuh asap kering dari lima tempat pengolahan yang berbeda di desa Tumpaan Baru, Kecamatan Tumpaan kemudian dibawa ke Laboratorium lalu dilakukan analisis kadar air dan uji organoleptik.

Berdasarkan hasil analisis kadar air ikan Japuh asap kering untuk masing-masing tempat pengolahan di desa Tumpaan Baru, ditemukan bahwa semua tempat pengolahan ini memenuhi nilai standar SNI yaitu $(<20 \%)$ sehingga dapat dikategorikan baik dan dari hasil uji organoleptik secara keseluruhan dapat dinyatakan bahwa ikan Japuh asap kering yang diolah oleh salah satu tempat pengolahan merupakan produk ikan Japuh asap kering yang paling baik atau paling disukai oleh konsumen.
\end{abstract}

Kata kunci: Ikan tandipang asap kering, mutu, tempat pengolahan.

\section{PENDAHULUAN}

Berbagai cara pengawetan ikan secara tradisional telah dilakukan saat ini dengan tujuan untuk mengurangi kadar air dalam tubuh ikan, sehingga tidak dapat memberikan kesempatan pada bakteri (mikroba) untuk hidup dan berkembang, serta dapat memperpanjang masa simpan atau mempertahankan daya awet ikan (Berhimpon, $d k k$., 2002).

Pengasapan merupakan salah satu cara pengolahan ikan yang berfungsi untuk mengawetkan serta memberi aroma dengan cita rasa yang khas. Di Sulawesi Utara terdapat bebarapa jenis ikan sebagai sumber daya ikan yang potensial dikembangkan. Salah satu produk yang yang sudah dikenal adalah produk Ikan Japuh (Dussumieria acuta C.V) yang diasapi atau lebih dikenal dengan sebutan Tandipang asap kering yang dihasilkan dari proses pengeringan yang dikombinasikan dengan pengasapan. Produk olahan ini masih bersifat tradisional, karena masih menggunakan cara sederhana dalam teknis pengolahannya seperti penggunaan bahan bakar yang diperoleh dari lingkungan sekitar seperti batang kelapa, tempurung kelapa dan sabut kelapa serta pengeringannya masih dilakukan dengan bantuan sinar matahari.

Salah satu pusat pengolahan ikan Japuh asap kering terdapat di kecamatan Tumpaan khususnya di desa Tumpaan Baru. Desa ini terletak tidak terlalu jauh dari pantai $(<2 \mathrm{~km})$, sehingga memiliki potensi yang cukup baik dibidang perikanan terutama perikanan laut. Industri pengolahan ikan Japuh asap kering merupakan suatu usaha kecil yang dikelola oleh masyarakat pesisir pantai yang ada di Kecamatan Tumpaan khususnya di desa Tumpaan Baru. Industri rumah tangga ini sudah ada sejak dulu dan merupakan warisan turuntemurun.

Hasil tangkapan dari ikan Japuh untuk tahun 2007 berkisar \pm 35 ton/tahun sedangkan untuk tahun $2008 \pm 30$ ton/tahun (DKP,2008). Industri pengolahan ikan japuh asap kering semakin diharapkan dapat terus berkembang 
menjadi industri rumah tangga yang dapat menghasilkan nilai tambah bagi para pengolah.

Saat ini di desa Tumpaan Baru ada sekitar 8 industri rumah tangga yang memproduksi ikan Japuh asap kering, dan biasanya ikan tandipang asap kering yang dihasilkan memiliki kualitas yang berbeda meskipun proses pengolahan dan bahan bakar yang digunakan hampir sama.

Berdasarkan hasil tinjauan di lapangan menyatakan bahwa hasil dari industri pengolahan ikan Japuh asap kering yang dijalankan makin berkembang atau makin diminati oleh masyarakat. Hal ini terbukti bahwa sudah banyak permintaan dari luar daerah.

Dari uraian di atas, maka perlu melakukan penelitian tentang karakteristik mutu ikan Japuh asap kering yang dihasilkan oleh para pengolah untuk mendapatkan gambaran umum mutu produk ikan dari setiap industri pengolah ikan tandipang asap kering tersebut. Penelitian ini bertujuan untuk mengetahui mutu ikan Japuh asap kering produksi rumah tangga di Desa Tumpaan Baru, Kec. Tumpaan, berdasarkan kadar air dan organoleptik.

\section{METODOLOGI PENELITIAN}

\section{Bahan dan Alat}

Bahan penelitian yang akan digunakan adalah ikan Japuh asap kering dan plastik polyetilene (PE) sebagai pembungkus sampel. Peralatan yang akan digunakan untuk analisis kadar air yaitu: timbangan, cawan porselen, oven dan desikator. Sedangkan untuk uji organoleptik yaitu: piring dan sekat.

\section{Tata Laksana Penelitian}

Ikan Japuh mentah diperoleh dari para nelayan, kemudian dibawa ke tempat pengolah dan dilakukan pencucian dengan air tawar kemudian di atur pada rak-rak. Setelah ikan Japuh selesai disusun, selanjutnya dilakukan pengasapan dengan lama pengasapan tergantung dari ukuran ikan. Setelah proses pengasapan dirasa cukup maka selanjutnya ikan berserta rak-raknya diangkat dan dikeringkan dengan menggunakan sinar matahari. Setelah ikan tandipang tersebut dirasa sudah cukup kering maka selanjutnya ikan disimpan dengan cara rak-raknya disusun kemudian dibungkus dengan terpal.

Sampel ikan Japuh asap kering diambil dari lima tempat pengolahan industri rumah tangga yang berada (dimana jarak antara tempat pengolah yang satu dengan yang lainnya berkisar 50-100 meter) di Desa Tumpaan Baru, Kecamatan Tumpaan, Kabupaten Minahasa Selatan. Cara pengambilannya yaitu, sampel ikan Japuh asap kering dari setiap tempat pengolah diangkat dari rak kemudian dimasukkan dan dikemas dalam plastik PE (untuk menjaga agar ikan tidak bereaksi secara kimiawi dengan bahan kemasan) dengan memisahkan sampel untuk masing-masing tempat pengolahnya. Setelah itu sampel kemudian dibawa ke laboratorium (waktu tempuh kira-kira sekitar 1,5 jam) untuk dilakukan pengujian. Pengujian yang dilakukan adalah kadar air dan organoleptik.

\section{HASIL DAN PEMBAHASAN}

\section{Analisis Kadar Air}

Hasil analisis kadar air ikan Japuh asap kering yang diperolah dari 5 tempat pengolahan yang berbeda di desa Tumpaan Baru, kec. Tumpaan dapat dilihat pada Tabel 1. Berdasarkan data Tabel 1 tersebut dapat dilihat bahwa nilai rata-rata kadar air tertinggi berada pada ikan Japuh asap kering yang berasal dari tempat pengolah ke-5 yaitu $12,78 \%$, sedangkan nilai rata-rata kadar air terendah berada pada ikan Japuh asap kering yang berasal dari tempat pengolah ke-3 yaitu 7,53\%.

Tabel 1. Data hasil analisis kadar air ikan Japuh asap kering.

\begin{tabular}{lrrrr}
\hline \multirow{2}{*}{$\begin{array}{c}\text { Tempat } \\
\text { Pengolahan } \\
\text { Ikan }\end{array}$} & \multicolumn{2}{c}{$\begin{array}{c}\text { Hasil Analisis } \\
\text { Kadar Air }\end{array}$} & Jumlah & \multicolumn{1}{c}{$\begin{array}{c}\text { Rata- } \\
\text { rata }\end{array}$} \\
\cline { 2 - 3 } I & \multicolumn{1}{c}{ II } & & \\
\hline Pengolah I & 9,51 & 9,45 & 18,96 & 9,48 \\
Pengolah II & 10,84 & 10,44 & 21,28 & 10,64 \\
Pengolah III & 7,59 & 7,47 & 15,06 & 7,53 \\
Pengolah IV & 8,55 & 8,92 & 17,47 & 8,74 \\
Pengolah V & 12,53 & 13,02 & 25,55 & 12,78 \\
\hline
\end{tabular}

Hubungan antara beberapa tempat pengolahan ikan Japuh asap kering di desa Tumpaan Baru terhadap nilai kadar air dapat dilihat pada Gambar 1. Berdasarkan Gambar 1 dapat dilihat bahwa masing-masing tempat pengolahan ikan Japuh asap kering memiliki nilai kadar air yang berbeda-beda. Hal ini kemungkinan dipengaruhi oleh suhu dan lamanya waktu pengasapan dan pengeringan, serta juga lamanya ikan yang telah mengalami penyimpanan setelah proses pengolahan.

Harikedua (1992) menyatakan bahwa suhu dan lama pengasapan mempengaruhi nilai kadar air. Hal ini dikarenakan selama proses 
pengasapan berlangsung terjadi penguapan molekul-molekul air dari produk yang diasapi. Lebih lanjut Morintoh (2004) menyatakan bahwa semakin lama waktu pengasapan yang dilakukan maka akan semakin rendah kandungan air dalam produk tersebut.

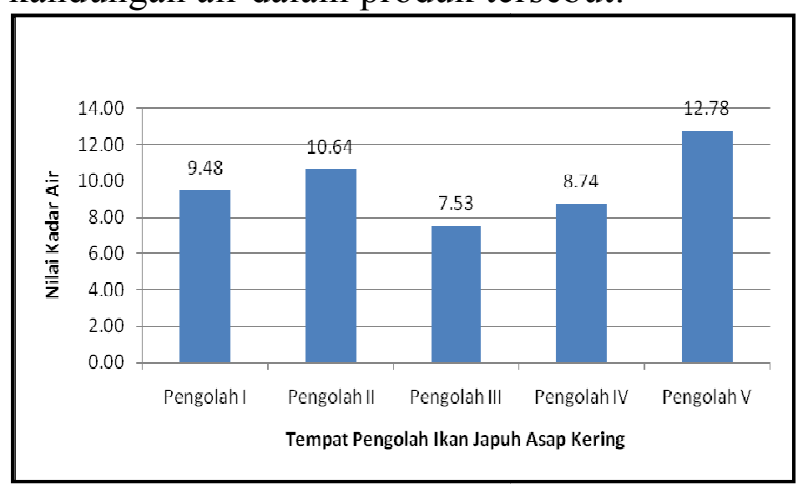

Gambar 1. Histogram nilai rata-rata kadar air ikan Japuh asap kering yang diperoleh dari beberapa tempat pengolah.

Menurut Moeljanto (1992) pengeringan didasari atas terjadinya penguapan air karena adanya perbedaan kandungan uap air antara udara dengan produk yang dikeringkan. Kandungan uap air udara lebih rendah dari kandungan uap air produk sehingga dapat terjadi penguapan. Makin besar perbedaan tersebut, makin banyak kandungan uap air produk yang dikeringkan dapat menguap. Faktor yang dapat mengakibatkan produk kehilangan berat dalam hal ini terjadi pengurangan kadar air selama proses pengeringan adalah lama pengeringan, suhu pengeringan, luas permukaan produk, jenis dan ukuran ikan serta jumlah garam yang diberikan (Earle, 1979) dalam (Ruus, 2009).

Berdasarkan hasil penelitian Enampato (2011) manyatakan bahwa setiap industri pengolahan ikan Japuh asap kering di desa Matani juga memiliki kandungan kadar air yang berbeda-beda. Perbedaan kadar air ini juga kemungkinan diakibatkan oleh lamanya waktu penyimpanan setelah pengeringan. Dari hasil penelitian Kaparang (2011) dan Poluakan (2011) menyatakan bahwa semakin lama produk ikan asap yang disimpan pada suhu ruang, maka semakin tinggi kadar air dari produk tersebut. Hal ini diduga disebabkan oleh karena kelembaban ruangan yang tinggi dan mengakibatkan produk menyerap air dari lingkungan. Menurut Purnomo (1995), naiknya kadar air disebabkan karena kelembaban ruangan penyimpanan lebih tinggi dari produk sehingga produk akan menyerap air yang mengakibatkan kadar air produk menjadi tinggi.

Berdasarkan Standar Nasional Indonesia (SNI) menurut BSN (2009) nilai kadar air produk ikan kering maksimal 20\%. Bila dibandingkan dengan produk ikan Japuh asap kering dari kelima tempat pengolahan tersebut maka dapat dinyatakan masih sesuai dengan standar.

\section{Uji Organoleptik \\ Kenampakan}

Hasil uji organoleptik terhadap kenampakan ikan Japuh asap kering yang diperolah dari 5 tempat pengolahan yang berbeda di desa Tumpaan Baru, Kec. Tumpaan dapat dilihat pada Tabel 2.

Berdasarkan data Tabel 2 tersebut dapat dilihat bahwa nilai rata-rata kenampakan tertinggi berada pada ikan Japuh asap kering yang berasal dari tempat pengolah ke-3 yaitu 8,13 , sedangkan nilai rata-rata kenampakan terendah berada pada ikan Japuh asap kering yang berasal dari tempat pengolah ke-5 yaitu 7,20 .

Tabel 2. Data nilai organoleptik kenampakan ikan Japuh asap kering.

\begin{tabular}{lccrr}
\hline \multirow{2}{*}{$\begin{array}{c}\text { Tempat } \\
\text { Pengolahan } \\
\text { Ikan }\end{array}$} & \multicolumn{2}{c}{$\begin{array}{c}\text { Nilai Organoleptik } \\
\text { Kenampakan }\end{array}$} & Jumlah & $\begin{array}{c}\text { Rata- } \\
\text { rata }\end{array}$ \\
\cline { 2 - 3 } I & \multicolumn{1}{c}{ II } & & 7,20 & 7,60 \\
Pengolah I & 7,67 & 7,53 & 15,20 & 7,47 \\
Pengolah II & 7,27 & 7,67 & 14,93 & 7,13 \\
Pengolah III & 8,20 & 8,07 & 16,27 & 8,13 \\
Pengolah IV & 8,07 & 7,80 & 15,87 & 7,93 \\
Pengolah V & 7,27 & 7,13 & 14,40 & 7,20 \\
\hline
\end{tabular}

Kenampakan ikan Japuh asap kering dari ke-5 tempat pengolah dapat dilihat pada Gambar 2. Hubungan antara beberapa tempat pengolahan ikan Japuh asap kering di desa Tumpaan Baru terhadap nilai uji organoleptik kenampakan dapat dilihat pada Gambar 3.

Berdasarkan Gambar 3 dapat dilihat bahwa dari hasil uji organoleptik kenampakan ikan Japuh asap kering memiliki nilai yang bervariasi untuk setiap tempat pengolah. Hal ini kemungkinan dikarenakan asap yang diserap oleh tubuh ikan sangat bervariasi (tergantung dari jenis bahan bakar yang digunakan) sehingga memungkinkan warna pada permukaan ikan juga berbeda. Selain itu jumlah kadar air juga dapat mempengaruhi nilai kenampakan tersebut, dimana semakin tinggi kadar airnya maka nilai kenampakannya semakin rendah. 
Menurut Afrianto dan Liviawati (1989), zat-zat kimia yang dihasilkan dari pembakaran bahan bakar dalam proses pengasapan dapat memberikan warna kuning keemasan dan dapat memberikan daya tarik pada konsumen. Lebih lanjut dikatakan Moeljanto (1992), warna yang dikehendaki oleh konsumen sebagai warna ideal dari ikan hasil proses pengasapan adalah warana kuning emas kecoklatan. Menurut Soesono (1985), pengasapan bertujuan untuk memberikan warna serta rasa yang khas pada ikan, sehingga dapat dinyatakan bahwa semakin lama ikan diasapi maka semakin banyak jumlah zat-zat dalam asap yang diterima sesuai dengan produk akhir yang diinginkan. Lebih lanjut berdasarkan penelitian Morintoh (2004) menyatakan bahwa ikan yang diasapi selama 12 jam lebih baik kenampakannya dari pada ikan yang diasapi hanya 6 jam.

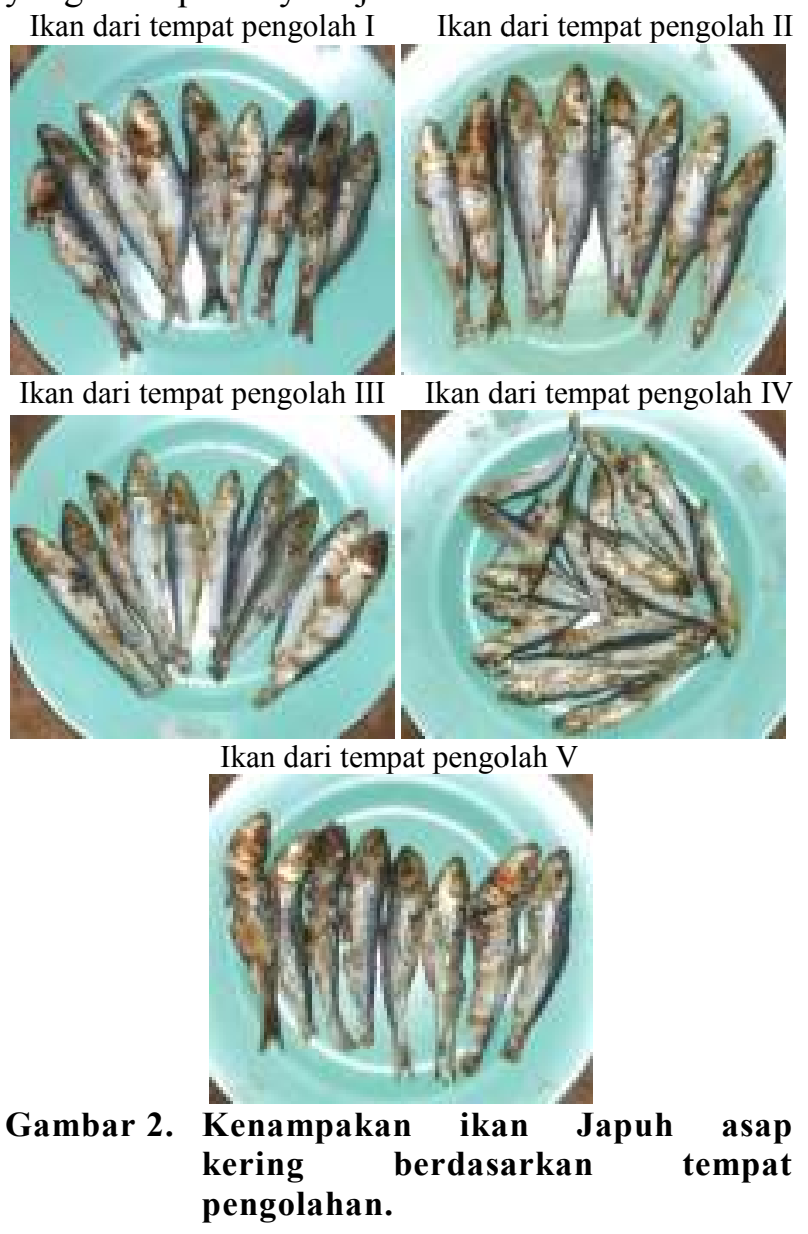

Perbedaan nilai kenampakan ini juga kemungkinan diakibatkan oleh karena ikan Japuh asap kering telah mengalami penyimpanan sehingga memungkinkan bertambahnya jumlah kadar air dan terjadinya penguapan zat-zat kimia yang membentuk warna kuning keemasan menjadi pudar.
Perubahan warna produk yang diasapi pada umumnya terjadi akibat senyawa-senyawa yang terdapat pada ikan mengalami oksidasi. Terjadinya peristiwa oksidasi ini tidak terlepas dari peran oksigen sehingga membuat kontak yang bebas dengan udara (Hadiwiyoto, 1993).

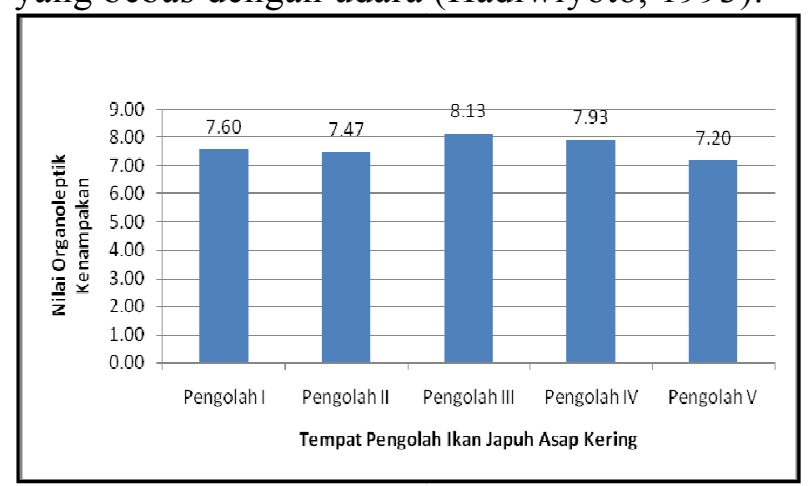

Gambar 3. Histogram nilai rata-rata uji organoleptik kenampakan ikan Japuh asap kering yang diperolah dari beberapa tempat pengolah.

Tabel 3. Data nilai organoleptik bau Ikan Japuh asap kering.

\begin{tabular}{|c|c|c|c|c|}
\hline \multirow{2}{*}{$\begin{array}{c}\text { Tempat } \\
\text { Pengolahan } \\
\text { Ikan }\end{array}$} & \multicolumn{2}{|c|}{$\begin{array}{c}\text { Nilai Organoleptik } \\
\text { Bau }\end{array}$} & \multirow[t]{2}{*}{ Jumlah } & \multirow{2}{*}{$\begin{array}{l}\text { Rata- } \\
\text { rata }\end{array}$} \\
\hline & I & II & & \\
\hline Pengolah I & 8,33 & 8,20 & 16,53 & 8,27 \\
\hline Pengolah II & 8,20 & 7,93 & 16,13 & 8,07 \\
\hline Pengolah III & 8,60 & 8,47 & 17,07 & 8,53 \\
\hline Pengolah IV & 8,47 & 8,33 & 16,80 & 8,40 \\
\hline Pengolah V & 7,93 & 7,93 & 15,87 & 7,93 \\
\hline
\end{tabular}

Bau

Hasil uji organoleptik terhadap bau ikan Japuh asap kering yang diperolah dari 5 tempat pengolahan yang berbeda di desa Tumpaan Baru, Kec. Tumpaan dapat dilihat pada Tabel 3. Berdasarkan data Tabel 3 tersebut dapat dilihat bahwa nilai rata-rata bau tertinggi berada pada ikan Japuh asap kering yang berasal dari tempat pengolah ke-3 yaitu 8,53 , sedangkan nilai ratarata bau terendah berada pada ikan tandipang asap kering yang berasal dari tempat pengolah ke-5 yaitu 7,93. Hubungan antara beberapa tempat pengolahan ikan Japuh asap kering di desa Tumpaan Baru terhadap nilai uji organoleptik Bau dapat dilihat pada Gambar 4.

Berdasarkan Gambar 4 dapat dilihat bahwa dari hasil uji organoleptik bau ikan tandipang asap kering memiliki nilai yang bervariasi untuk setiap tempat pengolah. Hal ini kemungkinan dikarenakan asap yang dihasilkan dari bahan bakar dan lama proses pengasapan sangat bervariasi sehingga memungkinkan bau pada ikan juga berbeda. Selain itu jumlah kadar air mempengaruhi nilai bau tersebut, dimana 
semakin tinggi kadar airnya maka nilai baunya semakin rendah.

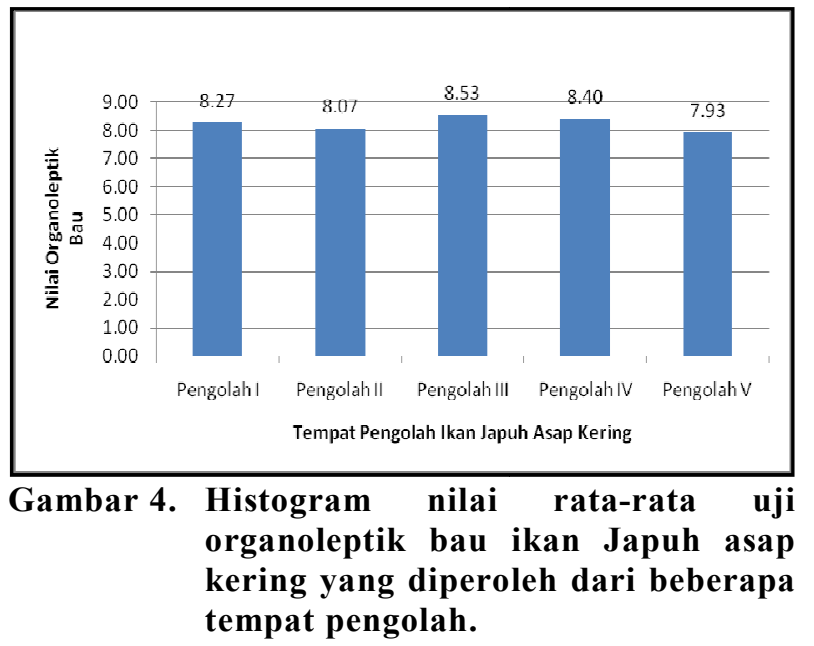

Menurut Randal dan Bratzler (1970) dalam Kapoh (1995), zat-zat yang mendominasi pembentukan bau adalah komponen-komponen asap yang melekat pada produk seperti fenol. Wibowo (2000) menyatakan bahwa kriteria mutu bau untuk ikan asap adalah bau asap yang lembut sampai cukup tajam atau tajam, tidak tengik, tanpa bau busuk, tanpa bau asing, tanpa bau asam dan tanpa bau apek.

Berdasarkan hasil penelitian Morintoh (2004), ikan yang diasap selama 12 jam lebih baik baunya dibanding ikan yang diasap selama 6 jam. Dengan demikian dapat dinyatakan bahwa semakin lama waktu pengasapan maka akan semakin baik baunya sesuai dengan jenis produk akhir yang diinginkan.

\section{Rasa}

Hasil uji organoleptik terhadap rasa ikan Japuh asap kering yang diperolah dari 5 tempat pengolahan yang berbeda di desa Tumpaan Baru, Kec. Tumpaan dapat dilihat pada Tabel 4.

Tabel 4. Data nilai organoleptik rasa ikan Japuh asap kering.

\begin{tabular}{|c|c|c|c|c|}
\hline \multirow{2}{*}{$\begin{array}{c}\text { Tempat } \\
\text { Pengolahan } \\
\text { Ikan }\end{array}$} & \multirow{2}{*}{\multicolumn{2}{|c|}{$\begin{array}{c}\text { Nilai Organoleptik } \\
\text { Rasa }\end{array}$}} & \multirow{2}{*}{ Jumlah } & \multirow{2}{*}{$\begin{array}{l}\text { Rata- } \\
\text { rata }\end{array}$} \\
\hline & & & & \\
\hline Pengolah I & 8,33 & 7,93 & 16,27 & 8,13 \\
\hline Pengolah II & 8,33 & 7,67 & 16,00 & 8,00 \\
\hline Pengolah III & 8,33 & 8,47 & 16,80 & 8,40 \\
\hline Pengolah IV & 8,33 & 8,07 & 16,40 & 8,20 \\
\hline Pengolah V & 7,67 & 7,80 & 15,47 & 7,73 \\
\hline
\end{tabular}

Berdasarkan data Tabel 4 tersebut dapat dilihat bahwa nilai rata-rata rasa tertinggi berada pada ikan Japuh asap kering yang berasal dari tempat pengolah ke-3 yaitu 8,40 , sedangkan nilai rata-rata rasa terendah berada pada ikan tandipang asap kering yang berasal dari tempat pengolah ke-5 yaitu 7,73.

Hubungan antara beberapa tempat pengolahan ikan Japuh asap kering di desa Tumpaan Baru terhadap nilai uji organoleptik rasa dapat dilihat pada Gambar 5.

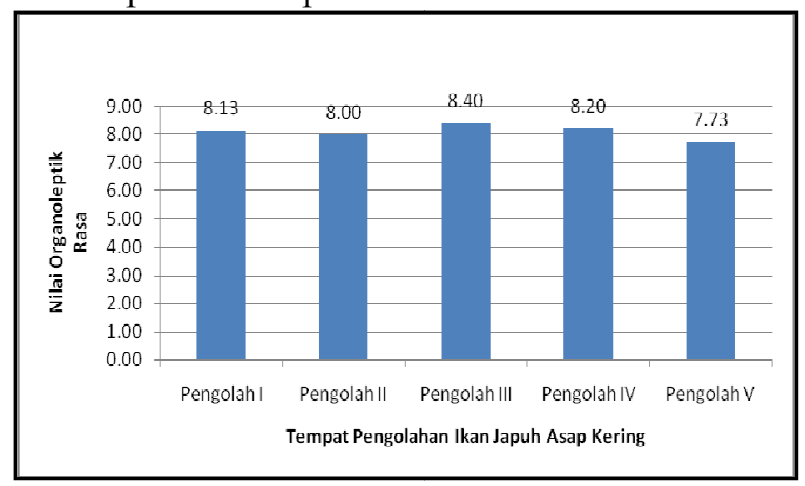

Gambar 5. Histogram nilai rata-rata uji organoleptik rasa ikan Japuh asap kering yang diperoleh dari beberapa tempat pengolah.

Berdasarkan Gambar 5 dapat dilihat bahwa dari hasil uji organoleptik rasa ikan Japuh asap kering memiliki nilai yang bervariasi untuk setiap tempat pengolah. Hal ini kemungkinan dikarenakan asap yang diserap oleh tubuh ikan sangat bervariasi sehingga memungkinkan rasa pada permukaan ikan juga berbeda. Selain itu jumlah kadar air mempengaruhi nilai rasa tersebut, diman semakin tinggi kadar airnya maka nilai rasa semakin rendah. Hal ini kemungkinan karena semakin rendah kadar air maka kandungan asap dalam produk semakin terkonsentrasi. Berdasarkan hasil penelitian Komansilan (2011) manyatakan bahwa nilai rasa ikan asap sangat dipengaruhi oleh lama waktu penyimpanan, lamanya proses pengasapan serta tungku tempat pengasapan.

\section{Tekstur}

Hasil uji organoleptik terhadap tekstur ikan Japuh asap kering yang diperolah dari 5 tempat pengolahan yang berbeda di desa Tumpaan Baru, kec. Tumpaan dapat dilihat pada Tabel 5.

Tabel 5. Data nilai organoleptik tekstur ikan Japuh asap kering.

\begin{tabular}{lcrrr}
\hline \multirow{2}{*}{$\begin{array}{c}\text { Tempat } \\
\text { Pengolahan } \\
\text { Ikan }\end{array}$} & \multicolumn{2}{c}{$\begin{array}{c}\text { Nilai Organoleptik } \\
\text { Tekstur }\end{array}$} & Jumlah & $\begin{array}{c}\text { Rata- } \\
\text { rata }\end{array}$ \\
\cline { 2 - 3 } I & \multicolumn{1}{c}{ II } & & \\
\hline Pengolah I & 7,80 & 8,07 & 15,87 & 7,93 \\
Pengolah II & 7,67 & 7,80 & 15,47 & 7,73 \\
Pengolah III & 8,47 & 8,47 & 16,93 & 8,47 \\
Pengolah IV & 8,07 & 8,33 & 16,40 & 8,20 \\
Pengolah V & 7,40 & 7,27 & 14,67 & 7,33 \\
\hline
\end{tabular}


Berdasarkan data Tabel 5 tersebut dapat dilihat bahwa nilai rata-rata tekstur tertinggi berada pada ikan Japuh asap kering yang berasal dari tempat pengolah ke-3 yaitu 8,47 , sedangkan nilai rata-rata tekstur terendah berada pada ikan Japuh asap kering yang berasal dari tempat pengolah ke-5 yaitu 7,33. Hubungan antara beberapa tempat pengolahan ikan Japuh asap kering di desa Tumpaan Baru terhadap nilai uji organoleptik Tekstur dapat dilihat pada Gambar 6.

Berdasarkan Gambar 6 dapat dilihat bahwa dari hasil uji organoleptik tekstur ikan Japuh asap kering memiliki nilai yang bervariasi untuk setiap tempat pengolah. Dari histogram tersebut dapat dilihat bahwa nilai tekstur ikan Japuh asap kering sangat berkaitan erat dengan jumlah kadar air dari bahan/produk tersebut. Nilai tekstur berbanding terbalik dengan nilai kadar air, artinya bahwa jika jumlah kadar air dari ikan asap kering menurun maka nilai teksturnya akan semakin meningkat. Demikian juga sebaliknya jika jumlah kadar air meningkat maka nilai teksturnya akan semakin menurun.

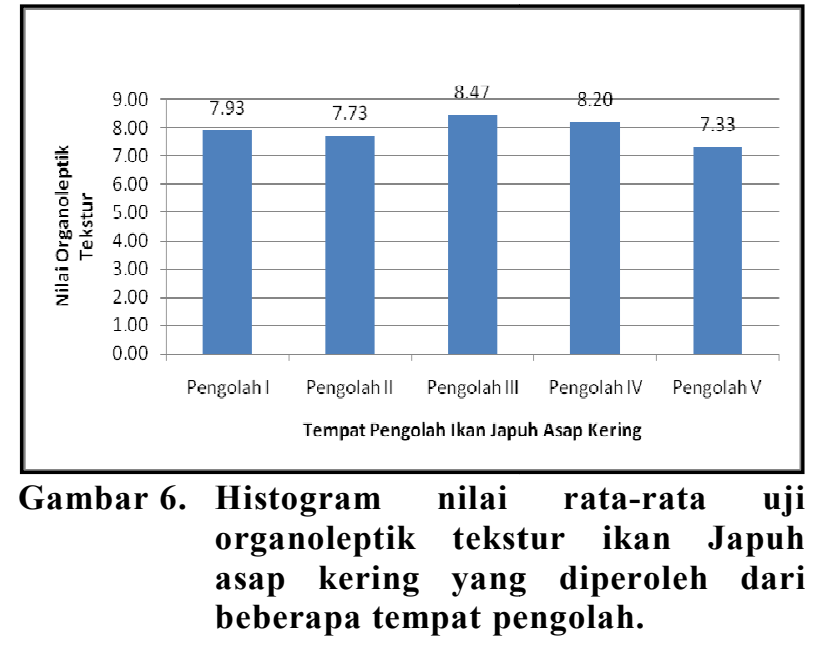

Dari hasil penelitian Enampato (2011) menyatakan bahwa semakin rendah jumlah kadar air dari ikan asap kering maka nilai teksturnya semakin tinggi. Hal ini dikarenakan daging ikan semakin padat atau keras seiring menurunnya kadar air dari tubuh ikan. Perbedaan nilai tekstur pada ikan asap kering yang diperoleh dari 5 tempat pengolah tersebut juga kemungkinan dipengaruhi oleh lamanya menyimpanan sejak produk ikan asap kering tersebut diolah. Komansilan (2011) menyatakan bahwa semakin lama ikan asap yang disimpan pada suhu ruang maka nilai teksturnya semakin menurun. Hadiwiyoto (1993) menyatakan bahwa perubahan tekstur ikan disebabkan oleh komponan-komponen penyusun jaringan pangikat dan benang-benang daging yang telah rusak sebagai akibat dari perubahan biokimiawi dan mikrobiologik. Kerusakan struktur jaringan akan menyebabkan daging ikan akan kehilangan sifat kelenturannya dan kepadatannya menjadi sangat lunak. Faktor yang sangat berperan penting terhadap perubahan ini adalah suhu dan waktu.

Menurut Berhimpon (1995), perubahan dimana tekstur daging menjadi lunak disebabkan karena mulai terjadi perombakan jaringan otot ikan karena proses enzimatis yang berasal dari ikan itu sendiri dan juga dari mikroba. Disamping itu, dengan suhu penyimpanan yang berkisar antara $29-33^{\circ} \mathrm{C}$ menyebabkan adanya penyerapan uap air dari lingkungan sehingga terjadi kenaikan kandungan air pada daging ikan asap. Dengan demikian dapat dinyatakan bahwa tinggi rendahnya nilai tekstur sangat dipengaruhi oleh jumlah kadar air dari ikan tandipang asap kering tersebut.

\section{KESIMPULAN DAN SARAN}

\section{Kesimpulan}

Berdasarkan hasil diatas dapat disimpulkan bahwa:

- Produk ikan Japuh asap kering di desa Tumpaan Baru, Kecamatan Tumpaan semuanya memiliki nilai kadar air yang sesuai dengan standar SNI $<20 \%$. Sehingga dapat dinyatakan bahwa produk tersebut memiliki kualitas yang baik.

- Pada uji organoleptik semua parameter uji memiliki nilai yang sesuai dengan standar SNI yaitu $>7$ dan dari hasil nilai tersebut memperlihatkan bahwa ikan Japuh asap kering yang diolah dari tempat pengolahan ke-3 merupakan produk ikan Japuh asap kering yang paling baik atau paling disukai oleh konsumen.

\section{Saran}

Perlu mempertahankan mutu ikan Japuh asap kering sehingga tetap disukai oleh masyarakat dan lebih meningkatkan produksinya.

\section{DAFTAR PUSTAKA}

Afrianto, E., dan E. Liviawaty., 1989. Pengawetan dan Pengolahan Ikan. Kanisius. Yogyakarta.

Badan Standarisasi Nasional (BSN). 2009. Standarisasi Nasional Indonesia : Ikan Asap. Jakarta. 
Berhimpon, S., F. G. Ijong dan P. Moniharapon, 2002. Penilaian Indera. Penuntun Praktikum. FPIK UNSRAT. Manado.

Dinas Kelautan dan Perikanan (DKP). 2008. Produksi ikan Japuh (Dussumieria acuta C.V.) Asap Kering. Dinas Perikanan dan Kelautan Minahasa Selatan. Sulut.

Enampato, M.H. 2011. Inventarisasi Keragaman Mutu Produk Ikan Tandipang (Dussumieria acuta C.V.) Asap Kering Produksi Rumah Tangga Didesa Matani I Kecamatan Tumpaan. Skripsi. Fakultas Perikanan dan Ilmu Kelautan. UNSRAT. Manado.

Harikedua, J. W. 2002. Metode Analisis Kimia Hasil Perikanan. Penuntun Praktikum. Fakultas Perikanan. UNSRAT. Manado.

Kaparang, R. N. 2011. Penentuan Mutu Ikan Tandipang (Dussumieria acuta C.V.) Asap Kering Selama Penyimpanan Suhu Kamar. Skripsi. Fakultas Perikanan dan Ilmu Kelautan. UNSRAT. Manado.
Komansilan, S. E. 2011. Keberadaan Tungku Pengasapan Berbeda dan Lama Penyimpanan Terhadap Mutu Cakalang (Katsuwonus pelamis. L) Asap. Skripsi. Fakultas Perikanan. UNSRAT. Manado.

Moeljanto. 1992. Pengolahan dan Pengawetan Hasil Perikanan. Penebar Swadaya. Jakarta.

Poluakan, T. B. 2011. Daya Awet Ikan Japuh (Dussumieeria acuta C.V.) Asap Kering dari Desa Matani Satu Kecamatan Tumpaan yang Disimpan pada Suhu Ruang dengan Pengemas dan Tanpa Pengemas. Skrips. Fakultas Perikanan dan Ilmu Kelautan. UNSRAT. Manado.

Soeseno. 1985. Teknik Penangkapan dan Teknologi Ikan. Yasaguna. Jakarta.

Wibowo, S. 2000. Industri Pengasapan Ikan. Penebar Swadaya. Jakarta. 